\title{
PERKEMBANGAN BAHASA ARAB DI INDONESIA
}

\author{
Muhammad Zainuri \\ Pascasarjana UIN Sunan Kalijaga Yogyakarta \\ zainurimuhammad266@gmail.com
}

\begin{abstract}
Abstrak
Selama ini pengkaji atau pendidik bahasa Arab tampaknya baru sekedar memposisikan bahasa Arab sebagai alat (wasîlah) untuk memahami teks keIslaman yang berbahasa Arab dan belum memfungsikannya sebagai sebuah disiplin ilmu yang perlu dikembangkan melalui berbagai penelitian dan pembacaan kembali secara kritis. Tantangan dan berbagai persoalan yang dihadapi pendidikan bahasa Arab tidak mungkin dapat dipecahkan secara personal, tetapi harus melalui pendekatan institusional dan melibatkan banyak pihak. Pendidikan bahasa Arab sebagai peluang yang dapat memberikan prospek yang lebih cerah dan menjanjikan bagi peminat dan penggiat studi bahasa Arab di masa depan. Epistemologi keilmuan dan kurikulum perlu dibenahi dan diorientasikan kepadapembentukan kemahiran yang kompetitif di era global ini. Semua itu menuntut banyak pihak untuk bersinergi dalam menyatukan visi, misi, arah kebijakan dan pengembangan yang dilandasi oleh kajian akademik yang mendalam.
\end{abstract}

Kata Kunci: Prospek, Pendidikan, Bahasa Arab 


\begin{abstract}
This study departs from the basic assumption that a literary work, including the poem which is the main study of this article, is not an ordinary work. In it, a poet has an idea to convey through the language he uses. Most poems in it carry the value of life, messages, impressions and so on. The language of poetry is not a language that is used in general even though the language is often used by the general public. The poet has his own meaning in the language. When the readers do not understand the meaning of the language used by the poet, the language has no meaning. The readers are required to be critical and interpret the language used by the poet to understand the meaning of the language used by the poet. This paper reviews the poetry of Al-Lughah al-'Arabiyyah Tan'a Hadzaha Bayna Ahliha by Hafidz Ibrahim with the language approach of Ferdinand de Saussure's Semiotics theory. It aims to reveal the meaning behind the language of the poet.
\end{abstract}

Keywords: Poetry, language, semiotics.

\title{
ملخص البحث
}

لايـزال الباحــث أو مــدرس اللغــة العربيــة إلى اليـوم يجعــل اللغــة العربيـة كوسـيلة لفهـم النصـوص الإسـلامية المكتوبـة باللغـة العربيـة، وفم يجعلهـا كعلـم يحتـاج إلى تطويـر ودراسـة وقـراءة نقديـة. إن المعوقـات والكشـاكل المتعلقــة باللغـة العربيـة لايكـن حلهـا عـن طريـق الأفـراد. وإنهـا يهكـن حلهـا عـن طريـق الهيئـة التـي تشـمل أفـرادا كثيريـن. واللغــة العربيـة تعطـي فرصـة لســتقبل مـشرق لنشـطاء ومحـركي تعليـم اللغـة العربيـة. ولابــ مـن إصـلاح وتوجيـه أصـول ونظريـة العلـم والطنهـه نحــو إنشـاء المهـارة المتنافسـة في هـذا العـر الحديـث. وهـذه الأمـور تطالـب تعـاون جميـع الأطـراف في توحيــ الرأيـة والرسـالة وتوجـهـ السياسـة والتطويـر اعتـمادا عـلى دراسـة علميـة متعمقــة. الكلمة ألأساسية :مستقبل، تعليم، اللغة العربي 


\section{A. Pendahuluan}

Bahasa arab merupakan salah satu bahasa asing yang sangat populer dan sering sekali dipelajari oleh para pelajar, khususnya di Indonesia. Dalam perkembangan pembelajaran bahasa Arab di Indonesia seringkali guru atau siswa (sebagai komponen utama dalam pembelajaran) mengalami berbagai kesulitan dan permasalahan pembelajaran, baik persoalan yang bersumber dari siswa maupun masalah-masalah yang dihadapi oleh guru, sehingga dapat menghambat pada ketercapaian tujuan pembelajaran dengan baik. Hal ini dapat dimaklumi, mengingat banyaknya perbedaan-perbedaan sistem antara bahasa Arab sebagai bahasa kedua yang dipelajari dan sistem bahasa Indonesia yang sudah melekat erat pada diri siswa di Indonesia.

Bahasa adalah bunyi yang bersifat arbitrar, digunakan oleh manusia sebagai alat komunikasi antar sesama dan memiliki makna. Bahasa merupakan hasil dari pembiasaan (language is habit) tanpa pembiasaan tidak akan ada bahasa, bahasa memiliki berbagai fungsi dan karakteristik, salah satunya adalah kreatif dan mengikuti zaman dengan kata lain bahasa merupakan suatu yang dinamis.

Bahasa Arab merupakan salah satu bahasa Internasional yang digunakan oleh ummat manusia untuk berkomunikasi antar satu sama lain, di dalam buku The arabic language dinyatakan bahwa bahasa Arab telah digunakan oleh lebih dari 150 juta orang sebagai bahasa ibu atau bahasa sehari-hari mereka, dan tidak ada bukti dokumentasi yang menyatakan bahwa bahasa Arab adalah bahasa tertua apabila dibanding dengan bahasa lainnya, namun juga tidak dapat dipastikan bahwa bahasa Arab jauh lebih muda dibanding bahasa lainnya (Hidayat, 1988:57).

Sejauh ini belum ada hasil penelitian yang memastikan sejak kapan studi bahasa Arab di Indonesia mulai dirintis dan dikembangkan. Asumsi yang selama ini berkembang adalah bahwa bahasa Arab sudah mulai dikenal oleh bangsa Indonesia sejak Islam dikenal dan dianut oleh mayoritas bangsa kita. Jika Islam secara meluas telah dianut oleh masyarakat kita pada abad 
ke 13, maka usia pendidikan bahasa Arab dipastikan sudah lebih dari 7 abad. Karena perjumpaan umat Islam Indonesia dengan bahasa Arab itu paralel dengan perjumpaannya dengan Islam. Dengan demikian, bahasa Arab di Indonesia jauh lebih "tua dan senior" dibandingkan dengan bahasa asing lainnya, seperti: Belanda, Inggris, Portugal, Mandarin, dan Jepang.

Namun demikian, jika dibandingkan dengan bahasa Inggris yang bercitra lebih baik, mengapa citra dan apresiasi masyarakat Indonesia (yang mayoritas penduduk Muslim yang merupakan komunitas Muslim terbesar di dunia) terhadap bahasa Arab tampaknya kurang menggembirakan? Apakah posisi bahasa Arab sebagai bahasa kitab suci al-Qur'an dan sunnah Nabi Muhammad Saw., selama ini tidak cukup memberikan daya dorong (inspirasi dan motivasi) bagi umat Islam untuk mau mengkajinya secara lebih intens? Apakah studi basaha Arab di Indonesia hanya dipacu oleh semangat (motivasi) untuk memahami ajaran Islam semata, dan terbatas di kalangan kaum tradisional "santri” saja, sehingga studi bahasa Arab kurang mendapatkan momentum untuk berkembang sebagai sebuah disiplin ilmu dan menarik minat banyak kalangan? Dan jika bahasa Arab harus direfungsionalisasi, baik secara ilmiah-akademik maupun profesionalpragmatik, bagaimana hal ini dapat dilakukan?

Bisa jadi pertanyaan tersebut ada benarnya, terutama jika dihubungkan dengan kesan sebagian besar orang bahwa bahasa Arab itu sulit dipelajari, dipahami, dipraktikkan; tidak seperti (misalnya) bahasa Inggris atau Mandarin. Tingkat kesulitan dalam mempelajari bahasa Arab diduga kuat karena ilmu bahasa Arab itu sudah cukup matang, komplit dan sekaligus kompleks. Mitos apa yang sesungguhnya menghantui sulitnya mempelajari dan menguasai bahasa Arab?

Menurut 'Abd al-Shabûr Syâhîn, pendidikan bahasa Arab dewasa ini dihadapkan pada berbagai tantangan yang serius. Pertama, akibat globalisasi, penggunaan bahasa Arab fushha di kalangan masyarakat Arab sendiri mulai berkurang frekuensi dan proporsinya, cenderung digantikan dengan bahasa Arab 'âmmiyah atau dialek lokal (al-lahajât almahalliyah). 
Jika jumlah negera Arab berjumlah 22 negera, berarti paling tidak ada 22 ragam bahasa 'ammiyah. Hal ini belum termasuk dialek sukusuku dan kawasan-kawasan tertentu. Misalnya, dialek lokal Iskandaria (Alexandria) tidak sama dengan dialek Thantha, dan sebagainya.

\section{B. Pengembangan Epistemologi dan Kurikulum Bahasa Arab}

Tantangan dan berbagai persoalan yang dihadapi pendidikan bahasa Arab tidak mungkin dapat dipecahkan secara personal, tetapi harus melalui pendekatan institusional dan melibatkan banyak pihak. Selain ada upaya penggantian huruf Arab dengan latin, bahasa Arab pada lembaga pendidikan di dunia Islam juga mulai digeser (meskipun belum sampai digantikan) oleh bahasa Inggris atau Perancis sebagai bahasa pengantar untuk pembelajaran sains. Berbagai siaran langsung olah raga di dunia Arab, terutama sepakbola, yang disiarkan dari Barat (liga Inggris, Spanyol, Italia, Perancis, atau Belanda) sudah banyak menggunakan bahasa Inggris. Demikian pula, mata acara atau program tayangan televisi di dunia Arab juga sudah banyak dipengaruhi oleh gaya dan pola hidup Barat yang sekuler dan materialistik. Akibatnya, minat dan motivasi untuk mempelajari bahasa Arab secara serius menjadi menurun.

Ada tiga kesulitan yang sering menjadi problema komunikasi bagi pembelajar bahasa kedua (bahasa asing), yaitu: 1) kesulitan dalam pemilihan arti, 2) kesulitan dalam pemilihan bentuk, dan 3) kesulitan dalam pemilihan Rules of Speaking. Yang dimaksud dengan pemilihan arti adalah pemilihan konsep, ide, harapan, emosi, dan sebagainya yang ingin dikomunikasikan oleh pembelajar bahasa kedua. Pembelajar bahasa kedua sering mengalami kesulitan dalam upayanya untuk mengekspresikan arti, karena terbatasnya bekal bahasa target yang dimiliki. Ini menyebabkan pemilihan alternatif pemecahan kesulitan pun sukar diperoleh (Nurhadi, 2010:84).

Kesalahan berbahasa sering terjadi ketika seseorang sedang mempelajari bahasa asing, baik itu dalam hal pengucapan maupun penulisan. Hal itu disebabkan banyaknya perbedaan antara bahasa asing 
dengan bahasa yang biasa dipakai oleh pelajar. Seperti halnya bahasa Arab, bahasa yang diketahui sebagai bahasa yang digunakan kitab suci umat Islam yakni Al- Qur'an, pada dasarnya sudah sewajarnya apabila umat Islam mampu atau mahir berbahasa Arab karena bahasa ini sudah tidak asing lagi bagi mereka, bagaimana tidak? Bahasa arab sudah sering digunakkan oleh umat Islam diberbagai negara di belahan dunia untuk mereka beribadah. Namun, untuk mempelajari bahasa asing terutama bahasa Arab memang tidak semudah mempelajari bahasa ibu atau bahasa asli orang 'ajam (orang yang bukan asli dari Arab) tersebut. mengingat bahasa Arab merupakan bahasa yang sangat kompleks butuh kerja keras untuk mempelajarinya.

Di Indonesia, seperti yang diketahui merupakan negara yang mayoritas penduduknya memeluk agama Islam, namun fakta tersebut tidak menjadikan mereka mampu berbahasa Arab dengan baik atau minimal memahaminya. Ironis memang, ketika orang-orang orientalis diluar sana berbondong-bondong untuk mempelajari bahasa umat Islam tersebut, akan tetapi umatnya sendiri tidak memiliki kemahiran berbahasa Arab atau bahkan tidak memiliki ketertarikkan untuk mempelajarinya.

Bahasa Arab tak ubahnya bahasa Asing lain di dunia. Ia tumbuh dan berkembang sesuai kepentingan orang-orang yang menggunakannya. Suatu bahasa hidup atau mati sangat ditentukan oleh sejauh mana masyarakat memakainya dalam berbagai aspek kehidupan mereka. Suatu bahasa dikatakan hidup jika masyarakat masih memakainya dalam kehidupan sehari-hari dan dikatakan mati jika sebaliknya (Mu'in, 2004:24).

Bagi bangsa Indonesia dalam mempelajari Bahasa Arab di samping ada kemudahan juga ada kesukaran. Yang demikian itu bisa saja terjadi, karena bagaimanapun Bahasa Arab adalah bahasa asing, yang sistem tata bunyi (phonology), tata bahasa (nahwu dan sharaf) dan tata tulis (imla') nya berbeda dengan bahasa Indonesia. Kemudahan-kemudahan itu muncul bila antara B1 (bahasa Indonesia) dengan B2 (bahasa Arab) banyak mempunyai persamaan (Mu'in, 2004:7). 
Dalam hipotesis kontrastif dikatakan bahwa seringkali seseorang melakukan kesalahan dalam mengungkapkan sebuah kalimat akibat pengaruh kontruksi kalimat bahasa pertamanya, dan kebalikannya pada keadaan tertentu ia dimudahkan cara belajarnya oleh bahasa pertamanya. Menurut hipotesis kontrastif, yang dikembangkan oleh Charles Fries dan Robert Lado, kesalahan yang dibuat tersebut disebabkan oleh adanya perbedaan antara bahasa pertama dan bahasa kedua, sedangkan kemudahan dalam belajarnya disebabkan oleh adanya kesamaan-kesamaan antar unsur B1 (bahasa pertama/ bahasa Indonesia) dan B2 (bahasa asing/bahasa Arab) menyebabkan kesulitan, sedangkan persamaan menyebabkan kemudahan (Nurhadi, 2010:5).

Salah Satu keuntungan bagi bangsa Indonesia, karena bahasa Indonesia banyak mengambil bahasa Arab sebagai bahasa nasional. Seperti kata : musyawarah, khusus, nikmat, manfaat, faham, tamat, tawakal, tafakur, dan lain-lain. Sedangkan perbedaanya terletak pada tata bunyi. Tidak sedikit huruf Arab yang tidak ada persamaannya dalam (bahasa Indonesia). Selain itu kesukaran dalam tata bahasa (sintaksis) adalah susunan katakata dalam suatu kalimat. Susunan tersebut dalam bahasa Arab disebut Jumlah (baik ismiyah maupun filiyah). Disamping itu juga dikenal dengan susunan subjek dan predikat untuk kalimat aktif, dan dalam susunannya tanpa membedakan jenis kata dan jumlahnya.

Kendatipun demikian tidak sedikit sekolah-sekolah atau Instansi pendidikan yang menjadikan bahasa Arab sebagai salah satu program studi atau mata pelajaran wajib yang harus diikuti oleh siswa, seperti sekolahsekolah yang berada di bawah Kementerian Agama. Berbagai upaya pun dilakukan dalam rangka mencari metode pengajaran yang tepat, berbagai diskusi dan seminar sering diselenggarakan baik oleh pemerintah maupuninstansi pendidikan demi untuk perkembangan pembelajaran bahasa Arab di Indonesia. Mengingat lemahnya pengetahuan bahasa Arab di kalangan masyarakat, sehingga kegiatan tersebut dibutuhkan dalam rangka melatih mahasiswa Program Studi Bahasa Arab maupun guru-guru. 
Di Indonesia bahasa Arab tidaklah asing dalam kehidupan umat Islam sejak dahulu kala, karena motif keagamaan merupakan alasan yang paling mendasar dalam mempelajarinya. Oleh karena itu studi bahasa Arab dan Islam di Indonesia, hampir merupakkan harus memperhatikan jenis kata dan jumlahnya, sedangkan untuk bahasa nasional dua hal yang tidak dapat dipisahkan. Dan kenyataan memang menunjukan bahwa kedua bidang studi tersebut hampir bersamaan. Bahasa Arab di Indonesia sama dikenalnya dengan agama Islam, atau dengan kata lain bahasa Arab sama tuanya dengan agama Islam. Namun bahasa Arab tetaplah bahasa asing bagi orang Indonesia. Jadi dalam belajar dan mengajar bahasa Arab terdapat kesulitan dan permasalahan baik itu secara linguistik maupun non- linguistik (Mu'in, 2004:40-41).

Dalam proses kegiatan pembelajarannya, kalimat atau kalam dalam bahasa Arab merupakan bagian dari tata bahasa atau struktur, maka kegiatan pembelajarannya menginduk kepada pembelajaran tata bahasa. Seperti yang diungkapkan oleh David Nunan bahwa perbedaan dasar dalam teori pembelajaran tata bahasa adalah antara pembelajaran deduktif dan induktif. Istilah "deduktif” mengacu pada pembelajaran yang mengenalkan atau memperlihatkan qaidah pada awal pelajaran kemudian dilanjutkandengan pemberian contoh dan penerapan. Sedangkan "induktif" adalah kebalikannya, yaitu qaidah diperlihatkan setelah diberikan contoh yang diperbandingkan terlebih dahulu (Helmi, 2011:4).

Pada pembelajaran kalam yang dalam hal ini merupakan bagian dari pembelajaran tata bahasa Arab, kedua istilah tersebut yakni deduktif dan induktif merupakan suatu metode pembelajaran. Berangkat dari pernyataan di atas maka penulis tertarik untuk meneliti lebih lanjut tentang perbandingan antara bahasa Arab dengan bahasa Indonesia terutama mengenai kalimat dalam sintaksis kedua bahasa tersebut dan bagaimana pembelajaran bahasa Arab bagi orang Indonesia berdasarkan analisis kontrastif kalimat dalam sintaksis bahasa Arab dan bahasa Indonesia. 
Tantangan dan berbagai persoalan yang dihadapi pendidikan bahasa Arab tidak mungkin dapat dipecahkan secara personal, tetapi harus melalui pendekatan institusional dan melibatkan banyak pihak. Selain ada upaya penggantian huruf Arab dengan latin, bahasa Arab pada lembaga pendidikan di dunia Islam juga mulai digeser (meskipun belum sampai digantikan) oleh bahasa Inggris atau Perancis sebagai bahasa pengantar untuk pembelajaran sains. Berbagai siaran langsung olah raga di dunia Arab, terutama sepakbola, yang disiarkan dari Barat (liga Inggris, Spanyol, Italia, Perancis, atau Belanda) sudah banyak menggunakan bahasa Inggris. Demikian pula, mata acara atau program tayangan televisi di dunia Arab juga sudah banyak dipengaruhi oleh gaya dan pola hidup Barat yang sekuler dan materialistic (al-Yûsuf, http://www.suhuf.net.sa/2000jaz/ $\mathrm{dec} / 10 / \mathrm{ar} 8 . \mathrm{htm})$. Akibatnya, minat dan motivasi untuk mempelajari bahasa Arab secara serius menjadi menurun.

Namun yang mendesak untuk kita diskusikan secara lebih mendalam adalah pengembangan epistemologi dan kurikulum bahasa Arab pada jurusan Pendidikan Bahasa Arab. Yang dimaksud dengan pengembangan epistemologi bahasa Arab adalah pengokohan bangunan keilmuan bahasa Arab agar arah pengembangan pengkajian bahasa Arab lebih dinamis. Dari bangunan epistemologi inilah, struktur keilmuan dapat dikembangkan lebih jauh dalam kurikulum bahasa Arab. Berikut ini adalah beberapa pokok pikiran mengenai model pengembangan epistemologi dan kurikulum bahasa Arab.

Pertama, revitalisasi sinergi ilmu bahasa Arab dan ilmu-ilmu lain yang mempunyai kedekatan bidang kajian, sehingga terjadi proses "take and give" (al-akhdz wa al- 'aţâ') seperti: ilm al-Naş (tekstologi) (Dijk, 2002), 'ilm al- makhaţûţat (filologi), 'ilm al-uşlûb (stilistika) dan sebagainya. Dengan demikian, ilmu bahasa Arab tidak hanya menjadi basis studi, tetapi juga mempunyai "jaringan keilmuan” yang lebih luas dan multifungsi. 
Kedua, pengembangan cabang-cabang bahasa Arab menjadi ilmu mandiri, seperti: 'ilm al-tarjamah, ilm al-insyâ, ilm uşûl al-nahwi, ilm alMu'jam (leksikografi) dan sebagainya, sehingga ilmu-ilmu ini tidakhanya sekedar "suplemen", tetapi menjadi ilmu yang lebih substantif, sistematis, dan mendalam ('Inani, 1992). Seiring dengan semakin menguatnya basis dan tradisi keilmuan, jika memungkinkan di suatu saat nanti, PBA (Pendidikan Bahasa Arab) dapat membuka program studi atau peminatan: metodologi penelitian bahasa Arab tarjamaah Arab-Indonesia, metodologi pembelajaran bahasa Arab, pengembangan kurikulum bahasa Arab, teknologi pendidikan bahasa Arab, dan sebagainya.

Ketiga, pembandingan, adaptasi, dan improvisasi ilmu bahasa Arab dengan bahasa Inggris dan Perancis yang saat ini lebih maju dan modern. Upaya ini sebetulnya sudah dilakukan, terutama dalam konteks pembagian metodologi pembelajaran bahasa Arab. Namun tokoh-tokoh pengembangnya relatif masih terbatas. Di antaranya adalah Kamâl Ibrâhîm Badrî, Muhammad Ismâ'îl Shînî, Rusydî Ahmad Thu'aimah, Mahmûd Kâmil al-Nâqah, Rusydî Khathir, Mahmud Fahmî Hijazi, Tammâm Hassân, dan Abduh al-Rajihî. Semua tokoh tersebut pernah mengenyam pendidikan tinggi di Barat, seperti Amerika, Perancis, Inggris, dan Jerman.

Salah satu faktor yang menyebabkan belum terwujudnya keterampilan ber-bahasa Arab di kalangan pembelajar adalah karena model dan strategi yang digunakan oleh pendidik selama ini kurang sesuai dengan jiwa dan karakter peserta didik. Peserta didik pada tingkat Madrasah Tsanawiyah pada umumnya telah akrab dengan komputer. Keakraban mereka dengan berbagai teknologi informasi dan komunikasi menuntut kreativitas dari pendidik untuk melaksanakan proses pembelajaran sesuai dengan jiwa dan kebutuhan mereka.

Model pembelajaran mengalami perkembangan secara terus-menerus seiring dengan perkembangan yang terjadi pada disiplin ilmu bahasa, ilmu pendidikan, dan arus perkembangan zaman. Lebih dari itu hasil-hasil penelitian dalam bidang pengajaran bahasa itu sendiri juga memberikan 
kontribusi pada lahirnya pendekatan dan metode baru dalam pengajaran bahasa (Faridi, 2009:59). Diakui bahwa sebagian besar dari perkembangan tersebut terjadi pada pengajaran bahasa Inggris sebagai bahasa dunia yang paling banyak peminatnya dewasa ini. Sedangkan pengajaran bahasa Arab lebih banyak berperan sebagai adopsiator sehingga seringkali tertinggal satu langkah dibandingkan pengajaran bahasa Inggris.

Model pembelajaran merupakan salah satu komponen penting dan memainkan peran yang besar dalam keberhasilan suatu program pendidikan. Pada dasarnya, model dimaksudkan menjadi payung utama untuk spesifikasi dan interelasi antara teori dan praktik. Apa yang dipahami siswa merupakan korpus dari model yang digunakan, meskipun terdapat sejumlah perbedaan model dalam belajar bahasa, teori bahasa tetap berasumsi bahwa bahasa adalah sebuah sistem kebiasaan dalam komunikasi.

Lahirnya strategi dan model yang telah ada selama ini belum memberikan kepuasan dan kelegaan di kalangan pembelajar bahasa, sesuai dengan perkembangan zaman di era kemajuan teknologi informasi dan komunikasi ini dunia pendidikan butuh dengan konsep pendidikan yang sinergi dengan kemajuan teknologi termasuk pembelajaran bahasa. Penelitian telah membuktikan bahwa model pembelajaran yang didukung dengan pemanfaatan media pembelajaran menunjukan dampak yang sangat signifikan terhadap kemampuan pembelajar memahami materi dibandingkan dengan system conventinal instruction (Hubbard, 2006:98). Pembelajaran yang hanya berdasarkan ceramah akan membantu pembelajar memahami materi hingga 5\%. Jika model pembelajaran berkembang dengan mereka membaca, presentasi akan meningkat menjadi 10\%, berturutturut audiovisual, demontsrasi, diskusi, latihan, dan saling mengajar akan mencapai mulai dari 20\% hingga 80\% (Baso, 2013:221).

Schramm (1977:86) mengemukakan bahwa bahwa materi pembelajaran sangat dipengaruhi oleh isi dan model instruksional serta jenis teknologi yang digunakan. Di sisi lain, Clark (1983:445-459) mengatakan bahwa penggunaan teknologi (komputer multimedia) dalam pembelajaran 
sangat membantu penyiapan materi secara efisien dan efektif. Komputer dapat berperan ganda dalam pembelajaran, termasuk pembelajaran bahasa Arab.

Penggunaan komputer untuk pembelajaran memang sudah dimulai sejak tahun 60-an (Syanab, 2007:66), namun komputer hanya berperan sebagai tutor yang menyajikan latihan-latihan, tetapi tidak dapat memberikan penilaian (feedback) dan pendekatan berupa reward dan punishment yang membantu peserta didik untuk termotivasi dalam belajar. Bahkan adanya komputerpun untuk belajar bahasa di berbagai sekolah tidak mampu meningkatkan motivasi mempelajari bahasa Arab di kalangan peserta didik. Keberadaan komputer juga belum serta merta membuat guru untuk merancang pembelajaran bahasa Arab secara kreatif dan inovatif. Fakta ini terjadi di beberapa MTs Negeri di kota Padang yang sudah memiliki basis secara nasional dan internasional. Komputer hanya dimanfaatkan untuk mata pelajaran yang bersifat umum seperti matematika, bahasa Indonesia, bahasa Inggris dan mata pelajaran umum lainnya, sementara untuk pembelajaran bahasa Arab keberadaan komputer tersebut belum dimanfaatkan oleh guru dan peserta didik.

Secara fundamental, pembelajaran berbasis TIK yang dalam penerapannya sangat mengutamakan penggunaan teknologi seperti komputer, sehingga lebih dikenal dengan istilah pembelajaran berbasis komputer atau Computer Based Instruction (CBI) ini merupakan sebuah proses pembelajaran yang menggunakan computer untuk menyajikan materi pembelajaran dengan memberikan kesempatan kepada peserta didik untuk berpartisifasi secara aktif dan merespon aktivitas siswa (Criswell, 1998:1). Bahkan pendapat yang lebih dalam dikemukakan oleh Made Wane (2009:203), pembelajaran berbasis TIK yang disajikan melalui komputer membuat kegiatan proses belajar mengajar menjadi lebih menarik dan menantang bagi peserta didik.

Kemampuan seorang guru dalam berbahasa tidak menjamin bahwa dia terampil dalam mengajarkan bahasa tersebut. Seorang guru bahasa Arab 
seharusnya memiliki setidaknya tiga keterampilan, yakni: 1) Kemahiran berbahasa Arab, 2) Pengetahuan tentang bahasa dan budaya Arab, 3) Keterampilan mengajar bahasa Arab (al-'Ushaili, 1423H:268). Berkaitan dengan ketiga syarat tersebut dan kaitannya dengan pembelajaran bahasa Arab berbasis teknologi informasi dan komunikasi seorang guru dituntut terampil memanfaatkan berbagai media teknologi dalam mengajarkan bahasa Arab. Hal ini suatu keharusan karena kemampuan membuat media dan menggunakannya merupakan bagian dari keterampilan mengajar bahasa.

Berdasarkan hasil wawancara dengan salah seorang guru Bahasa Arab, media komputer belum dimanfaatkan secara maksimal dalam mengajarkan bahasa Arab, pembelajaran bahasa Arab yang dilakukan selama ini mengacu kepada RPP yang disusun dari jauh hari dan tidak menggunakan komputer sebagai medianya. Hal ini menurutnya disebabkan belum adanya pedoman khusus yang dapat dijadikan sebagai acuan untuk mengintegrasikan TIK dalam dan dengan pembelajaran bahasa Arab. Pernyataan yang tidak jauh berbeda juga diungkapkan oleh Yogi (Wawancara, 20/03/2015) yang merasakan bahwa belajar bahasa Arab sebagai momok yang membosankan karena sistem pembelajarannya hanya bersumber dari LKS (Lembar Kerja Siswa) yang diberikan setiap awal semester, sementara media TIK belum dimanfaatkan untuk itu. Hal ini berbeda dengan pengajaran pada mata pelajaran lain yang telah memanfaatkan TIK dalam proses pembelajaran. Dalam hal ini ditegaskan bahwa dia telah terbiasa mengetik dengan menggunakan bahasa Inggris, namun bagaimana cara mengetik berbahasa Arab sama sekali belum pernah dipelajarinya.

Pemanfaatan TIK tidak terlepas dari problematika, diperlukan suatu upaya untuk menghadapi hambatan yang akan muncul dalam penerapan pembelajaran bahasa Arab berbasis TIK di MTs bagi guru. Terlebih lagi, jika meninjau dari aspek kemampuan pembelajaran guru selama ini yang memiliki kecenderungan tidak berani mencoba melakukan inovasi penerapan model pembelajarannya, maka tentu akan menjadi problematika 
awal bagi mereka dalam menerapkan pembelajaran bahasa Arab berbasis TIK tersebut. Kondisi ini juga semakin dipersulit dengan belum tersedianya pedoman khusus pelaksanaan pembelajaran bahasa Arab berbasis TIK tersebut bagi guru bahasa Arab. Belum tersedianya pedoman khusus pelaksanaan pembelajaran bahasa Arab berbasis TIK bagi guru merupakan indikasi belum terintegrasinya secara efektif antara dunia yang dekat kepada peserta didik dengan proses pembelajaran bahasa Arab.

\section{Analisis Kebutuhan Terhadap Model Pembelajaran Bahasa Arab Berbasis TIK}

Dalam rangka mengetahui model pembelajaran yang dibutuhkan lembaga pendidikan jenjang MTs peneliti melakukan kajian terhadap beberapa aspek, yakni kurikulum dan perangkat pembelajaran yang digunakan, kesulitan yang dihadapi peserta didik dan kendala yang dialami pendidik dalam pembelajaran bahasa Arab.

Berdasarkan hasil observasi, dokumentasi dan wawancara di tiga MTs Negeri di Kota Padang, yakni MTs Negeri Gunung Pangilun, MTs Negeri Durian Tarung dan MTs Negeri Lubuk Buaya, diketahui bahwa ketiga lembaga pendidikan tersebut menggunakan dua macam kurikulum, yaitu Kurikulum Tingkat Satuan Pendidikan dan Kurikulum 2013. Keanekaragaman kurikulum yang dipakai setidaknya mempengaruhi proses pembelajaran yang akan dilakukan dan menuntut kearifan pendidik dalam menyesuaikan segala aspek pembelajaran yang sesuai dengan dunia peserta didik. Pelaksanaan pembelajaran yang ada di ketiga MTs Negeri sebagaimana dijelaskan di atas menggunakan dua kurikulum. Kedua jenis kurikulum tersebut dalam pelaksanaannya diawali dengan menyiapkan perangkat pembelajaran seperti program tahunan, program semester, program bulanan, program mingguan dan membuat rencana pelaksanaan pembelajaran. Hal ini sesuai dengan pernyataan Refly Anwar (Wawancara, 09/09/2015), bahwa masing-masing guru tidak hanya guru bahasa Arab dituntut untuk dapat menyiapkan semua perangkat pembelajaran. 
Pernyataan senada juga diungkapkan oleh Kamarul Zaman (Wawancara, 14/09/2015) bahwa sebelum mulai program pembelajaran seluruh guru diharuskan mengumpulkan perangkat pembelajaran dan diserahkan kepada wakil kepala sekolah bidang kurikulum, tujuannya tidak lain untuk menjaga kulitas proses pembelajaran.

Ketersediaan perangkat pembelajaran tersebut juga diperkuat oleh pernyataan Nindita (Wawancara, 14/09/2015) yang mengatakan bahwa guru bahasa Arab selalu menjelaskan terlebih dahulu apa yang diharapkan ketika mempelajari sebuah materi pembelaran. Berdasarkan analisis perangkat pem-belajaran seperti rencana pelaksanaan pembelajaran diketahui banyak materi pembelajaran yang membutuhkan pe-ngembangan melalui integrasi dengan Teknologi Informasi dan Komunikasi (TIK), seperti materi aspek pengucapan huruf yang benar, materi percakapan dan yang tidak kalah pentingnya adalah tadrîb li mahârat al-istimâ' .

\section{Kesimpulan}

Dapat disimpulkan bahwa banyak persoalan dan tantangan pendidikan bahasa Arab yang perlu dihadapi, disikapi, dan dicarikan solusinya secara akademik dan (dalam batas-batas tertentu) secara politik. Isu pencitraan buruk terhadap bahasa Arab, penggantian fushhâ dengan âmmiyah, rendahnya minat dan motivasi sebagian peserta didik dalam belajar bahasa Arab seharusnya menyadarkan kita semua bahwa kita masih harus berpikir, bersikap, dan berdedikasi lebih optimal (dedicate more and more) untuk kemajuan pendidikan bahasa Arab di Indonesia.

Tantangan internal maupun eksternal pendidikan bahasa Arab harus kita jadikan sebagai peluang yang dapat memberikan prospek yang lebih cerah dan menjanjikan bagi peminat dan penggiat studi bahasa Arab di masa depan. Epistemologi keilmuan dan kurikulum perlu dibenahi dan diorientasikan kepada pembentukan kamahiran yang kompetitif di era global ini. Semua itu menuntut banyak pihak untuk bersinergi dalam 
Muhammad Zainuri

menyatukan visi, misi, arah kebijakan dan pengembangan yang dilandasi oleh kajian akademik yang mendalam. Selama lembaga pendidikan Islam masih eksis, prospek pendidikan bahasa Arab tetap akan cerah dan menjadi daya tarik tersendiri.

246 | | E-ISSN : 2614-4271 P-ISSN : 2599-1302 


\section{Daftar Pustaka}

'Inâni, Muhammad, Fann al-Tarjamah, Kairo: al-Syarikah al-Mishriyyah al-'Âlamiyyah, 1992.

al-'Ushaili,Abdul 'Aziz Ibrahim, Asâsiyat Ta'lîm al-Lughah al- 'Arabiyah Li an Nâthiqîn bi Lughât Ukhra, Riyadh: Jami'ah al-Imam Muhammad bin Su'ud al-Islamiyah, $1423 \mathrm{H}$.

al-Yûsuf, Manshûr ibn Shâlih, "al-Lughah al-'Arabiyyah wa Tahaddiyat al-'Ashr", diakses dari http://www.suhuf.net.sa/2000jaz/dec/10/ar8. htm, 01 April 2019

Baso, Yusring Sanusi, Program Multimedia Bahasa Arab, Padang: Prosiding PINBA IMLA, 2013.

Clark, Richard E., "Reconsidering Research on Learning from Media", dalam Journal JSTOR, 1983, Vol. 53, No. 4. pp. 445-459

Criswell, E. L, The Design of Combuter Based Instruction, New York: Macmillan Publishing Company, 1998.

Dijk, Teun A. van, 'Ilm al-Nashsh: Madkhal al-Mutadâkhil al-Ikhtishâshât, terj. Dari Textwissenscaft, eine interdiziplinare Einfuhrung oleh Said Hasan Buhairi, Kairo: Dâr al- Qâhirah, 2002.

Faridi, Abdurrahman, "Inovasi Pembelajaran Bahasa Inggris Berbasis ICT dalam Rangka Meningkatkan Mutu Pendidikan", dalam Journal Lembaran Ilmu Kependidikan, Jilid 38, No. 1, Juni 2009, hlm. 59

Helmi, Irfan, Studi Komparatif Pembelajaran Fiil Madhi dalam bahasa Arab dan Past Tense dalam Bahasa Inggris, Skripsi, Purwokerto : Jurusan Tarbiyah, 2011. 
Muhammad Zainuri

Hidayat, Musykilat Tadris Ta'lim Al Arabiyyah Fi Indonesia Wa 'Ilajiha, Jakarta: Al Muwajjahah FI Ta'limi Al lughoh Al Arobiyyah, 1988.

Hubbard, P., Learner Training for Effective Use of CALL. State College PA: Center for Advance Language Proficiency and Education and Research, 2006.

Mu'in, Abdul. Analisis Kontrastif Bahasa Arab dan Bahasa Indonesia (Telaah Terhadap Fonetik dan Morfologi). Jakarta: Pustaka Al Husna Baru. 2004.

Nurhhadi, Dimensi-dimensi dalam Belajar Bahasa Kedua, Bandung: Sinar Baru Algensindo, 2010.

Schramm, Wilbur, Asas-asas Komunikasi Antar Manusia, Terj. Agus Setiadi, Jakarta: LP3ES, 1977.

Syanab, Maysa'Abu, “Tiknulujia Ta'allum al-Lughah al-'Arabiyah”, dalam Journal al-Adab wa al-Tarbiyah, Sudan, Vol. 2, No. 32, 2007.

Wane, Made, Strategi Pembelajaran Inovatif Kontemporer, Jakarta: Bumi Aksara, 2009. 